Красинский Владислав Вячеславович, кандидат юридических наук, член Общественного консультативного научно-методического Совета при ЦИК России

Источник опубликования: Красинский $B . B$. О противодействии экстремизму в избирательном процессе // Право и образование. 2010. № 10. С. 133-143; www.krasinskiy.ru

\title{
О противодействии экстремизму в избирательном процессе
}

Аннотация: В статье рассмотрены законодательная основа и правоприменительная практика противодействия экстремистской деятельности в процессе организации и проведения выборов в России.

Ключевые слова: экстремистская деятельность, избирательный процесс, избирательная кампания, выборы, отказ в регистрации кандидата, исключение из списка кандидатов, отмена регистрации кандидата (списка), аннулирование регистрации кандидата, запрет экстремистской организации.

In article are considered a legislative basis and practice of counteraction of extremist activity in Russian electoral process.

Key words: extremist activity, electoral process, election campaign, elections, refusal in registration of the candidate, exception of the list of candidates, cancellation of registration of the candidate (list), interdiction of the extremist organisation.

Проходящие в Российской Федерации и за рубежом выборы в ряде случаев сопровождаются дестабилизацией обстановки и вплеском экстремистских проявлений. Экстремизм в избирательном процессе имеет двоякую природу: с одной стороны, он связан с низкой политической и правовой культурой участников выборов, недоверием к государственной власти, неготовностью к уступкам в политической борьбе, ориентацией на противоправные методы и насильственные средства достижения политических целей. С другой стороны, экстремистские проявления могут целенаправленно инспирироваться и поддерживаться экстремистскими организациями и радикально настроенными гражданами, преследующими цели ослабления, изменения и подрыва конституционного строя Российской Федерации, нанесения ущерба национальной безопасности [1, с. 239; 2, с. 118]. Экстремизму в избирательном процессе присущи: высокая степень общественной опасности, распространение экстремистской тематики во всех сферах общественной жизни, политизированные формы проявления (возбуждение национальной, расовой, религиозной или социальной розни; насильственное воспрепятствование осуществлению гражданами их избирательных прав, нарушение тайны голосования; воспрепятствование законной деятельности органов государственной власти, избирательных комиссий, общественных объединений; осуществление массовых беспорядков по мотивам ненависти или вражды).

Об актуальности противодействия экстремизму в связи с проведением федеральных избирательных кампаний по выборам депутатов Государственной Думы Федерального Собрания Российской Федерации 2007 г. и выборам 
Президента Российской Федерации 2008 г. свидетельствует внимание Президента Российской Федерации к этой проблеме. Выступая 31 января 2007 г. на Коллегии ФСБ России, Президент Российской Федерации отметил: «Важно не только обеспечить законность и правопорядок, но и обезопасить общество от попыток вброса в общественно-политическое поле идеологии экстремизма, национальной и конфессиональной нетерпимости» [3]. 9 марта 2007 г. на встрече в Кремле с высшими офицерами Президент Российской Федерации призвал органы федеральной службы безопасности не допустить использования в ходе избирательных кампаний лозунгов националистического и экстремистского характера [4].

Выборы дают возможность обнародования политических программ и участия сепаратистских, национал-радикальных и экстремистских организаций в массовых мероприятиях, открытой пропаганды их идеологических взглядов. Выборные кампании широко освещаются в СМИ, поэтому любое противоправное посягательство, направленное на изменение или подрыв конституционного строя, поданное под прикрытием оппозиционной или радикальной политической деятельности, приобретает широкий общественный резонанс [5, с.53].

В ходе избирательного процесса проводятся общественно-политические и иные массовые агитационные мероприятия с привлечением значительной части населения. С учетом возрастания угрозы террористических акций особую актуальность приобретает обеспечение безопасности населения в местах массового скопления граждан при подготовке и в ходе избирательных кампаний.

Предвыборные программы кандидатов, политических партий, иные агитационные материалы (в том числе размещаемые в информационнотелекоммуникационных сетях общего пользования, включая «Интернет»), выступления кандидатов и их доверенных лиц, представителей политических партий, граждан на публичных мероприятиях, в средствах массовой информации не должны содержать призывы к совершению деяний, определяемых в статье 1 Федерального закона от 25 июля 2002 года № 114-Ф3 «О противодействии экстремистской деятельности» как экстремистская деятельность, либо иным способом побуждать к таким деяниям, а также обосновывать или оправдывать экстремизм. В соответствии с Федеральным законом «О противодействии экстремистской деятельности» экстремистской деятельностью признается:

а) деятельность общественных и религиозных объединений либо иных организаций, либо редакций СМИ, либо физических лиц по планированию, организации, подготовке и совершению действий, направленных на:

- насильственное изменение основ конституционного строя и нарушение целостности Российской Федерации;

- подрыв безопасности Российской Федерации;

- захват или присвоение властных полномочий;

- создание незаконных вооруженных формирований; 
- осуществление террористической деятельности либо публичное оправдание терроризма;

- возбуждение расовой, национальной или религиозной розни, а также социальной розни, связанной с насилием или призывами к насилию;

- унижение национального достоинства;

- осуществление массовых беспорядков, хулиганских действий и актов вандализма по мотивам идеологической, политической, расовой, национальной или религиозной ненависти либо вражды, а равно по мотивам ненависти либо вражды в отношении какой-либо социальной группы;

- пропаганду исключительности, превосходства либо неполноценности граждан по признаку их отношения к религии, социальной, расовой, национальной, религиозной или языковой принадлежности;

- воспрепятствование законной деятельности органов государственной власти, избирательных комиссий, а также законной деятельности должностных лиц указанных органов, комиссий, соединенное с насилием или угрозой его применения;

- публичную клевету в отношении лица, замещающего государственную должность Российской Федерации или государственную должность субъекта Российской Федерации, при исполнении им своих должностных обязанностей или в связи с их исполнением, соединенную с обвинением указанного лица в совершении деяний, указанных в статье 1 упомянутого закона, при условии, что факт клеветы установлен в судебном порядке;

- применение насилия в отношении представителя государственной власти либо на угрозу применения насилия в отношении представителя государственной власти или его близких в связи с исполнением им своих должностных обязанностей;

- посягательство на жизнь государственного или общественного деятеля, совершенное в целях прекращения его государственной или иной политической деятельности либо из мести за такую деятельность;

- нарушение прав и свобод человека и гражданина, причинение вреда здоровью и имуществу граждан в связи с их убеждениями, расовой или национальной принадлежностью, вероисповеданием, социальной принадлежностью или социальным происхождением;

- создание и (или) распространение печатных, аудио-, аудиовизуальных и иных материалов (произведений), предназначенных для публичного использования и содержащих хотя бы один из признаков, предусмотренных указанной статьей;

б) пропаганда и публичное демонстрирование нацистской атрибутики или символики либо атрибутики или символики, сходных с нацистской атрибутикой или символикой до степени смешения;

в) публичные призывы к осуществлению указанной деятельности, а также публичные призывы и выступления, побуждающие к осуществлению указанной 
деятельности, обосновывающие либо оправдывающие совершение деяний, указанных в статье 1 указанного Федерального закона;

г) финансирование указанной деятельности либо иное содействие в планировании, организации, подготовке и совершении указанных действий, в том числе путем предоставления для осуществления указанной деятельности финансовых средств, недвижимости, учебной, полиграфической и материальнотехнической базы, телефонной, факсимильной и иных видов связи, информационных услуг, иных материально-технических средств.

Анализ содержания Федерального закона «О противодействии экстремистской деятельности» позволяет выявить ряд его недостатков.

1. В законе отсутствует научно-разработанное понятие экстремистской деятельности. Существующее определение экстремизма представляет собой простое перечисление составов преступлений.

2. Законодателем нечетко разграничена экстремистская и террористическая деятельность. Согласно пункту 1 статьи 1 Федерального закона «О противодействии экстремистской деятельности» публичное оправдание терроризма и иная террористическая деятельность являются составной частью экстремизма. Однако в Федеральных законах «О противодействии терроризму» и «О противодействии экстремистской деятельности» имеются составы преступлений, которые одновременно отнесены и к террористическим, и к экстремистским. Примером может служить состав, предусмотренный статьей 205.2 УК РФ «публичные призывы к осуществлению террористической деятельности или публичное оправдание терроризма». С другой стороны, если исходить из того, что терроризм - это компонент экстремизма, возникает вопрос, почему санкции за совершение преступлений экстремистской направленности существенно мягче.

3. Включение публичной клеветы в отношении лица, замещающего государственную должность Российской Федерации или государственную должность субъекта Российской Федерации, связанной с обвинением указанного лица в совершении экстремистских деяний, в состав экстремизма носит неоднозначный характер и потенциально позволяет использовать правовые положения Федерального закона «О противодействии экстремистской деятельности» в интересах лиц, замещающих государственные должности. Например, критика оппонентами высшего должностного лица субъекта Российской Федерации за проведение несбалансированной национально-кадровой политики в регионе формально-юридически может рассматриваться как экстремизм.

Запреты на подготовку и осуществление экстремистской деятельности в условиях выборов дополняются ограничениями, предусмотренными статьей 9 Федерального закона «О политических партиях». В соответствии с указанной статьей запрещается создание и деятельность политических партий, цели или действия которых направлены на осуществление экстремистской деятельности, a также создание политических партий по признакам профессиональной, расовой, национальной или религиозной принадлежности. 
Действующим законодательством предусмотрена возможность привлечения к ответственности организации телерадиовещания, редакции периодического печатного издания, их должностных лиц в случае нарушения порядка проведения предвыборной агитации и распространения экстремистских материалов (пункт 8 статьи 56 Федерального закона от 12 июня 2002 г. № 67-Ф3, статьи 8 и 11 Федерального закона «О противодействии экстремистской деятельности»). Федеральный закон от 4 июля 2003 года № 94Ф3 «О внесении изменений и дополнений в некоторые законодательные акты Российской Федерации в связи с принятием Федерального закона «Об основных гарантиях избирательных прав и права на участие в референдуме граждан Российской Федерации» дополнил Закон Российской Федерации от 27 декабря 1991 г. № 2141-I «О средствах массовой информации» статьей $16^{1}$ «Приостановление выпуска средства массовой информации за нарушение законодательства Российской Федерации о выборах и референдумах» [6].

Предусмотренная статьей $16^{1}$ процедура приостановления выпуска СМИ за нарушения законодательства о выборах чрезмерно сложна для практической реализации. Необходимость обращения в федеральный орган исполнительной власти, осуществляющий регистрацию СМИ, пятидневный срок, установленный для проверки фактов нарушения законодательства о выборах, возможность отказа уполномоченного федерального органа исполнительной власти от обращения в суд с заявлением о приостановлении выпуска СМИ позволяют СМИ-нарушителю длительное время безнаказанно продолжать противоправную деятельность, нарушающую законодательство о выборах. В связи с этим представляется целесообразным скорректировать содержание статьи $16^{1}$ Закона Российской Федерации от 27 декабря 1991 г. № 2141-I «O средствах массовой информации» следующим образом:

«Если в период избирательной кампании после вступления в силу решения суда о привлечении главного редактора или редакции радио-, телепрограммы, периодического печатного издания, иной организации, осуществляющей выпуск СМИ, к административной ответственности за нарушение законодательства о выборах этот главный редактор или эта организация допустит повторное нарушение законодательства о выборах, ЦИК России (в случае, если продукция СМИ распространяется на территории субъекта Российской Федерации также избирательная комиссия соответствующего субъекта Российской Федерации) обращается в федеральный орган исполнительной власти, осуществляющий регистрацию СМИ, с представлением о приостановлении выпуска данного СМИ. Указанный федеральный орган исполнительной власти немедленно осуществляет проверку фактов, изложенных в представлении, и обращается в суд с заявлением о приостановлении выпуска СМИ, использованного в целях совершения указанных нарушений. Приостановление выпуска СМИ осуществляется судом на срок до момента окончания голосования на выборах, а в случае, если проводится повторное голосование, - до момента окончания повторного голосования». 
Центральное место в обеспечении защиты конституционного строя России занимает совместная деятельность органов федеральной службы безопасности, прокуратуры и судов по противодействию экстремизму в избирательном процессе. Установленный судом в рамках уголовного дела, возбужденного органами федеральной службы безопасности, Следственного комитета при прокуратуре Российской Федерации факт подготовки и совершения экстремистской деятельности в период выборов является основанием для отказа в регистрации кандидата, списка кандидатов, исключения из списка кандидатов либо отмены регистрации кандидата, списка кандидатов (подпункт «к» пункта 24, подпункт «и» пункта 25, подпункт «3» пункта 26 статьи 38, подпункт «д» пункта 7, подпункт «д» пункта 8 статьи 76 Федерального закона от 12 июня 2002 г. № 67-Ф3).

В период досрочных выборов депутатов Совета народных депутатов Петушинского района решением Петушинского районного суда Владимирской области от 5 марта 2010 г. по заявлению окружной избирательной комиссии одномандатного избирательного округа № 17 была отменена регистрация кандидата в депутаты Совета народных депутатов Петушинского района Тиндикова А.А. по основаниям, предусмотренным подпунктом «д» пункта 7 статьи 76 Федерального закона «Об основных гарантиях избирательных прав и права на участие в референдуме граждан Российской Федерации» в связи с допущенным им нарушением пункта 1 статьи 56 данного закона.

В своем агитационном печатном материале «Рубеж-1» кандидат в депутаты Тиндиков А.А. допустил высказывания, направленные на возбуждение ненависти, вражды, унижение достоинства человека или группы лиц по признаку национальности, чем нарушил пункт 1 статьи 56 Федерального закона «Об основных гарантиях избирательных прав и права на участие в референдуме граждан Российской Федерации». Оценив содержание публикации Тиндикова, суд пришел к выводу о том, что в данной публикации содержатся высказывания, носящие признаки экстремистской деятельности: «Их пугает, что патриоты хотят очистить Россию от жидовского ига (это для них самое страшное), т.к. жиды - это и есть те писаки, которые падают в обморок от самого слова РУССКИЙ, и не разделяют понятия РУССКИЙ ПОЛИТИК и скинхед, пытаясь втоптать в грязь все святое, что связано со словом РУСЬ и РУССКИЙ.

Из представленного суду комплексного экспертного исследования, составленного экспертами ГУ «Владимирская лаборатория судебной экспертизы» 27 февраля 2010 г. за № 237Э, усматривается, что вышеназванные высказывания содержат следующие признаки возбуждения ненависти по признакам национальности: формирование отрицательного образа представителей национальной группы (евреев) путем утверждения об их неполноценности и порочности; утверждение о полярной противоположности и несовместимости интересов представителей этой национальной группы с интересами другой; приписывание им враждебных действий и опасных намерений. Из пояснений вызванной в качестве специалиста в судебное заседание Н., имеющей высшее филологическое образование и стаж работы по 
специальности более 30 лет, следует, что содержащееся в указанном печатном издании выражение «жидовское иго» содержит оскорбление не только для лиц, исповедующих иудаизм, но и лиц еврейской национальности, формирует презрительное и негативное отношение к ним и унижает национальное достоинство лиц еврейской национальности. С учетом установленных обстоятельств суд решил удовлетворить заявление окружной избирательной комиссии и отменить регистрацию кандидата в депутаты Совета народных депутатов Петушинского района по одномандатному избирательному округу № 17 Тиндикова Александра Александровича.

Если суд установит, что гражданин в ходе избирательной кампании использовал агитацию экстремистского характера, он лишается пассивного избирательного права на срок полномочий органа государственной власти или органа местного самоуправления, в которые назначены выборы, либо должностного лица, для избрания которого назначены выборы (подпункт «г» пункта 3.2 статьи 4 Федерального закона от 12 июня 2002 г. № 67-Ф3).

Примером судебной практики по данной категории дел может служить решение Заводского районного суда г. Саратова от 24 апреля 2008 г. и кассационное определение Судебной коллегии по гражданским делам Саратовского областного суда от 4 сентября 2008 г. Указанными судебными инстанциями было рассмотрено заявление кандидата в депутаты Михайлова С.Ю. о признании незаконным и отмене решения окружной избирательной комиссии избирательного округа № 6 от 17 марта 2008 г. № 51 «Об аннулировании регистрации зарегистрированного кандидата по дополнительным выборам депутата Саратовской городской Думы 3 созыва одномандатного избирательного округа № 6 Михайлова С.Ю.». Основанием аннулирования регистрации кандидата в депутаты Михайлова С.Ю. послужило то обстоятельство, что решением Октябрьского районного суда г. Саратова от 4 октября 2007 г., вступившим в законную силу 31 января 2008 г., был установлен факт, свидетельствующий о том, что Михайлов С.Ю. в средстве массовой информации, - в газете «Саратовский репортер», учредителем, главным редактором и единственным распространителем которой он являлся, совершил деяния, определяемые в статье 1 Федерального закона «О противодействии экстремистской деятельности». 12 сентября 2007 г. в адрес редакции газеты «Саратовский репортер» и в адрес учредителя и главного редактора указанной газеты Михайлова С.Ю. Средне-Волжским управлением Федеральной службы по надзору за соблюдением законодательства в сфере массовых коммуникаций и охране культурного наследия по результатам проверки статьи «Не бей жида - Россия спасена!» Э.Абросимова на основании статей 4 и 16 Закона РФ «О средствах массовой информации» и статей 5,8 Федерального закона «О противодействии экстремистской деятельности» было вынесено предупреждение о недопустимости экстремистской деятельности. Оспариваемым решением окружной избирательной комиссии заявитель был лишен возможности участвовать в выборах в Саратовскую городскую Думу на весь период ее полномочий, а также лишен права на обжалование решения 
окружной избирательной комиссии № 6 от 13 марта 2008 г. о признании результатов выборов недействительными.

Михайлов С.Ю. полагал, что аннулирование регистрации кандидата в депутаты возможно только в период до дня голосования по аналогии с отменой регистрации кандидата в депутаты. Однако его регистрация в качестве кандидата в депутаты была аннулирована избирательной комиссией после определения результатов выборов.

Представители окружной избирательной комиссии считали, что аннулирование регистрации кандидата в депутаты Михайлова С.Ю. возможно в период действия статуса зарегистрированного кандидата в депутаты, который в силу статьи 38 и пункта 5 статьи 41 Федерального закона «Об основных гарантиях избирательных прав и права на участие в референдуме граждан Российской Федерации» определен с момента принятия соответствующей избирательной комиссией решения о регистрации кандидата в депутаты до утраты данного статуса с момента официального опубликования (обнародования) общих данных о результатах выборов, а при досрочном выбытии - с даты выбытия. Тем самым, по мнению избирательной комиссии, решение комиссии об аннулировании регистрации кандидата в депутаты Михайлова С.Ю. было принято в период действия его статуса.

Заводской районный суд г. Саратова, изучив материалы дела и выслушав стороны, 24 апреля 2008 г. отменил решение окружной избирательной комиссии, исходя из следующего.

В соответствии с пунктом 30 статьи 38 Федерального закона «Об основных гарантиях избирательных прав и права на участие в референдуме граждан Российской Федерации» кандидат, выдвинутый непосредственно, не позднее чем за 5 дней до дня голосования, а при наличии вынуждающих обстоятельств не позднее чем за 1 день до дня голосования (в том числе повторного голосования) вправе представить в соответствующую избирательную комиссию письменное заявление о снятии своей кандидатуры. Если кандидат, выдвинутый непосредственно и подавший заявление о снятии своей кандидатуры, был зарегистрирован, зарегистрировавшая кандидата избирательная комиссия принимает решение об аннулировании его регистрации.

В силу пункта 32 статьи 38 Федерального закона «Об основных гарантиях избирательных прав и права на участие в референдуме граждан Российской Федерации» кандидат, выдвинутый по одномандатному избирательному округу, может быть отозван не позднее чем за 5 дней до дня голосования, а кандидат, включенный в список кандидатов, может быть исключен из этого списка не позднее чем за 15 дней до дня голосования. Согласно пункту 5 статьи 78 Федерального закона «Об основных гарантиях избирательных прав и права на участие в референдуме граждан Российской Федерации» заявление об отмене регистрации кандидата может быть подано в суд не позднее чем за 8 дней до дня голосования (в том числе повторного). Решение суда должно быть принято не позднее чем за 5 дней до дня голосования. Из смысла указанных норм Федерального закона «Об основных гарантиях избирательных прав и 
права на участие в референдуме граждан Российской Федерации» следует, что федеральный закон не содержит норм, указывающих на возможность отмены регистрации кандидата в депутаты или аннулирования регистрации кандидата в депутаты после проведения выборов. Все действия, направленные на снятие кандидата с участия в соответствующих выборах, должны производиться только до дня голосования. Действующим законодательством не предусмотрен самостоятельный срок, в течение которого регистрация кандидата может быть аннулирована. Суд посчитал, что действия окружной избирательной комиссии по аннулированию регистрации зарегистрированного кандидата в депутаты Михайлова С.Ю. должны были быть произведены до дня голосования не позднее чем за 1 день до дня голосования, по аналогии закона, а не после дня голосования и тем более после определения результатов выборов. На основании изложенного, суд признал решение окружной избирательной комиссии об аннулировании зарегистрированного кандидата в депутаты незаконным.

Проверив законность и обоснованность решения суда первой инстанции, судебная коллегия по гражданским делам Саратовского областного суда 4 сентября 2008 г. не нашла оснований для отмены судебного решения, принятого 24 апреля 2008 г. Заводским районным судом г. Саратова. Судебная коллегия согласилась с выводом суда первой инстанции о том, что аннулирование регистрации кандидата в депутаты может иметь место только до дня голосования. На следующих стадиях избирательной кампании аннулирование регистрации кандидата, отмена решения комиссии о регистрации кандидата, об отказе в регистрации кандидата, исключении кандидата из списка кандидатов, отмена регистрации кандидата теряют правовой смысл, поскольку после дня голосования вопрос об утрате кандидатом в депутаты пассивного избирательного права может быть рассмотрен только в качестве основания для отмены решения окружной избирательной комиссии об итогах голосования в том случае, если данное нарушение не позволило с достоверностью определить результаты волеизъявления избирателей, т.е. применительно к статье 77 Федерального закона «Об основных гарантиях избирательных прав и права на участие в референдуме граждан Российской Федерации». При таких обстоятельствах судебная коллегия пришла к выводу, что суд первой инстанции правомерно сослался в своем решении на нормы, регулирующие сходные правоотношения, поскольку содержащиеся в них положения об аннулировании отмене регистрации кандидатов в депутаты только до дня голосования соответствуют смыслу и духу действующего избирательного законодательства.

Подпунктом «в» пункта 2 статьи 77, пунктом 3 части 4 статьи 92 Федерального закона от 12 июня 2002 г. № 67-Ф3 предусмотрена возможность отмены судом решения Центральной избирательной комиссии Российской Федерации о результатах выборов депутатов Государственной Думы Федерального Собрания Российской Федерации после определения их результатов в случае использования кандидатом, признанным избранным, избирательным объединением, выдвинувшим список кандидатов, допущенный 
к распределению депутатских мандатов, экстремистской агитации, если нарушение данных ограничений при проведении предвыборной агитации не позволяет выявить действительную волю избирателей. Конституционноправовая ответственность не исключает применение уголовно-правовой (например, за публичные призывы к осуществлению террористической деятельности или публичное оправдание терроризма, публичные призывы к осуществлению экстремистской деятельности, возбуждение ненависти либо вражды, а равно унижение человеческого достоинства) либо административной (по статье 20.3 Кодекса Российской Федерации об административных правонарушениях) ответственности.

Так, в ходе выборов в Московскую областную Думу, проходивших 11 марта 2007 г., в помещении избирательного участка № 1763, расположенного в г. Одинцово, граждане Червочкин Ю.М., Климов С.В., Сидорин В.В. с целью воспрепятствования свободному осуществлению другими гражданами избирательных прав и работе избирательной комиссии развернули флаги с символикой Национал - большевистской партии, зажгли пиротехнические изделия, пытались разбрасывать листовки и перевернуть урну с бюллетенями, однако их противоправные действия были пресечены сотрудниками милиции. При этом данные граждане применили насилие к председателю избирательной комиссии - Стреляеву С.Ф. [7]. По данному факту прокуратурой г. Одинцово Московской области было возбуждено уголовное дело по признакам преступления, предусмотренного п. «в» ч. 2 ст. 141 УК РФ. 15 марта 2007 г. Одинцовской городской прокуратурой Московской области Национал большевистской партии было вынесено предупреждение о недопустимости действий экстремистского характера. Учитывая неоднократность экстремистских проявлений со стороны Национал - большевистской партии, задокументированных прокуратурами г. Санкт-Петербурга, Челябинской области и Одинцовской городской прокуратурой Московской области, в суд было направлено заявление о запрете деятельности указанной партии. 19 апреля 2007 г. Московский городской суд запретил Национал-большевистскую партию, а 7 августа 2007 г. данное решение было оставлено в силе Верховным Судом Российской Федерации.

В рамках противодействия экстремизму в избирательном процессе особую актуальность приобретают вопросы минимизации и пресечения массовых антиконституционных акций в ходе т.н. «цветных революций».

В целях противодействия экстремистской деятельности и массовым антиконституционным акциям статью 9 Федерального закона «О собраниях, митингах, демонстрациях, шествиях и пикетированиях» предлагается дополнить следующим предложением: «Запрещается проведение публичных мероприятий с момента окончания агитационного периода до официального опубликования результатов выборов». Аналогичную правовую норму можно было бы закрепить в пункте 3.1 статьи 49 и пункте 7.1 статьи 53 Федерального закона «Об основных гарантиях избирательных прав и права на участие в референдуме граждан Российской Федерации». 
Предложенное законодательное ограничение станет эффективным средством противодействия экстремизму, если будет органично дополнено комплексом социально-экономических, политических, информационнопропагандистских, организационно-правовых, кадровых и специальных мер защиты конституционного строя.

Одним только государственным принуждением и законодательными запретами не защитить конституционный строй. «Цветные революции» осуществляются при поддержке большинства граждан, составляющих социальную базу массовых экстремистских проявлений. Электоральная практика свидетельствует, что динамика протестного потенциала населения непосредственно связана с ухудшением материального положения и условий жизни большинства социальных групп, резким имущественным расслоением, непоследовательностью проводимого высшими должностными лицами экономического курса, коммерциализацией отраслей социальной сферы, политизацией организованной преступности, коррумпированностью высших эшелонов власти.

Механизм противодействия экстремистской деятельности в условиях выборов должен выстраиваться на основе мониторинга общественнополитической ситуации, разъяснительной работы с населением, профилактики конфликтов на национальной и религиозной почве, конструктивного сотрудничества с политическими силами, выступающими под умеренными националистическими лозунгами.

Примечания и ссылки на источники:

1. См.: Пиджаков А.Ю. Борьба с политическим экстремизмом и терроризмом: проблемы изучения // Правоведение. 2003. № 3. 1997.

2. См.: Романов Н.А. Политический экстремизм как угроза безопасности страны. М.,

3. Cм. http://archive.kremlin.ru/2007/01/31/news.

4. См. http://archive.kremlin.ru/2007/03/09/1839_type 63376_119347.shtml.

5. См.: Красинский В.В. Юридическое обеспечение выборов в интересах защиты конституционного строя и национальной безопасности. М.: Новый индекс, 2010. 552 с.

6. См. Рос. газ. 2003. 8 июля.

7. См. Решение Московского городского суда от 19 апреля 2007 г. о запрете Национал-большевистской партии. 